\title{
Study of Chauvinism in the Attitudes of the Intelligentsia during the Constitutional ERA
}

\author{
Dr. Mohammad ali Alizadeh ${ }^{1}$
}

Md.Ali Baghdar Delgosha²

\author{
${ }^{1}$ Department of History, Shahrood Branch, Islamic Azad University, Shahrood, Iran \\ ${ }^{2}$ Department of History, Mashhad Branch, Ferdowsi University, Mashhad, Iran
}

\author{
Doi:10.5901/mjss.2015.v6n4s1p165
}

\section{Abstract}

\begin{abstract}
The purpose of this study is to analyze the effects of chauvinism or extreme nationalism in the works of the intelligentsia during constitutional era. The importance of this historical era lies in the fact that it is seen as the inception of modernism in Iran. The intellectuals of that time, who tended to call their period the era of tyranny or despotism, were anxious to provide an explanation for the decline of Iranian history. In this regard, the major concern of the intelligentsia was the issue of patriotism or nationalism. Amongst the intelligentsia of this era, Fathali Akhondzadeh and Mirza Khan Kermani were the most prominent, who endeavored to present their nationalism under the veil of chauvinism and anti-Arabism, arguing that Arab invasion was the origin of historical decline of Iran.
\end{abstract}

Keywords: Intelligentsia, National traditions, Anti-Arabism, Constitutional Revolution, Chauvinism.

\section{Introduction}

After the French Revolution, the political ideas such as nationalism, liberalism and chauvinism found their way to the circles of intellectuals during Qajar era. Given the distinctive interpretations that the writers and intellectuals of that era held about the French Revolution, it used to be referred to with a variety of titles such as "Intrigue and Corruption", "Great Revolution" and "Eternal Spirit", which mirrored their different perceptions of that movement (Tavakoli Targhi, 1990: 412).

In light of the prevalence of political reforms and civil rights achievements, the Iranian intellectuals, who in the late $13^{\text {th }}(\mathrm{AH})$ and the early $14^{\text {th }}$ century were not much anxious about the demonstration of their ethnic identity, focused their attention on "fighting the tyranny and oppression of their rulers". (Enayat, 2010: 2). It was due to this awakening that Iranian intellectuals through political reforms and presentation of different definitions sought to prepare the ground for the introduction of ideological terms to Iran.

As to the introduction of nationalistic tendencies in Iran, it should be noted that the trails of growing attention to the ancient history of Iran during Qajar dynasty are evident since the reign of Fathali Shah, the devout and religious Shah of Iran and the measures of his grandson, Mohammad Shah Qajar, who was determined to promote the line of Pahalvi. This case suggests that not only intellectuals, but also kings and princes such as Jalaluddin Mirza Qajar were also fascinated with the ancient Iran and its history.Although the main concern of the intellectuals of this period was opposition against the internal tyranny of the regime, they were not oblivious of their "Beloved Homeland" and sought to reinforce their efforts to magnify the ancient history of Iran by adopting a nationalistic attitude.

Such hyperboles, rooted in "chauvinist tendencies" and accompanied with "anti-Arab" views (Ajoodani, 2008: 13) were evident in works of some of these intellectuals.

Among the intelligentsia, those like Akhoundzadeh (1917-1864) and Kermani (1934-1892) and amongst the princes, those like Jalaluddin Mirza, the son of Fathali Shah Qajar, strived to highlight the ancient history of Iran. It was in this atmosphere that Jalaluddin Mirza wrote the Book of Kings and Mirza Aqa Khan Kermani authored the Mirror of Alexander. Akhundzadeh, based on his intellectual tendencies, sent a letter to Maneckji, the Leader of Zoroastrian in Tehran, expressing that he was proud of being a "Persian" (Akhundzadeh, 1978: 249). Apparently it was the familiarity with that Qajar prince and the leader of Zoroastrian that added the flavor of anti-Arabism to his extreme chauvinism.

Mirza Fathali Akhundzadeh, whose nationalist views had first transformed into chauvinism after the meeting of Jalaluddin Mirza Qajar and then into anti-Arabism after the visit of Maneckji, was determined to establish his identity by negating the religious Arabic identity. The same attitude is evident in some of Kermani's works such as "Three Treaties and Hundreds of Sermons". 
The present study seeks to explore the influence of nationalism and national traditions on the attitudes of intelligentsias like Malcolm Khan, Tolibov, Mostashar al-Doula, Akhoundzadeh and Kirmani as well as the grounds that gave rise to the radical nationalism in form of chauvinism in the views of people like Akhoundzadeh and Kirmani and the influence of Zoroastrians such as Maneckji on the attitude of nationalism in Akhoundzadeh.

This study follows the precedent set by efforts of people like Admit in the "Views of Mirza Fathali Akhoundzadeh" and Ajoodani in the " Constitutional Revolution of Iran", aiming to explore the above cases at a broader scale based on the letters of Akhoundzadeh and treaties of Kermani.

\section{Chauvinism}

In studying the trends and political reforms of the Constitution, Iranian intellectuals, influenced by the Western principles, became cognizant of terms such as nationalism, radical nationalist in form of rejecting other nations called chauvinism, homeland, law, freedom and equality. It was natural that along with concepts such as law, justice and freedom, terms like patriotism and nationality were also proposed. It was the mission of Iranian intellectuals to obtain a single definition for these terms.

Akhundzadeh was one of the formulators of "Anti-constitutional discourse" (Tavakoli Targhi, 1990:423), which is attributed to people who hold a type of constitutional views that are different from the majority of constitutionalists in the society. In a few of his works such as the writings of Kamal al-Doula, he attempted to spread the application of terms like social justice in Iran. He was not, nonetheless, oblivious to concepts such as nation and homeland. At that time, patriotism and nationalism were so important that even the press, night letters and constitutional flayers were not free from the influence of national traditions. To shed further light on the concept of chauvinism, first the term nationalism needs to be explained. Nationalism, which is often regarded as "national consciousness", is associated with the loyalty and interest of individuals to the constituents of the nation (Ashuri, 1978:166). It is in keeping with this definition that "national government" becomes the supreme form of political organization (ibid .: 167), and the political unit, i.e. government, grows consistent and adaptable with the national unit, i.e. nation (Gellner,1999).

The term chauvinism, which has its origin in the nationalism, was derived from Nicolas Chauvin. He was a veteran of the French Emperor who lavished exaggerated compliments upon Napoleon. Later, this term was employed in the politics to refer to "exaggerated patriotism" (Ashuri, 1978: 121). In this context, the suffix 'ism' should also be note. As pointed by Raymond Aroy, this suffix is characterized by a set of qualities including an "emotional trait". It is more intended to "convince" rather than "express" something (Beshler, 1991: 8). Such statements that are expressive of an "ideology" associated with the political action (Beshler, 1991: 27) that developed under the term "Constitutional Revolution in Iran" (Beshler, 1991: 12).

In connection with the principles of constitutionalism and its subsequent intellectual movement, only the works of intellectual leaders of nationalism such as Mirza Fathali Akhoundi and Jalaluddin Mirza Qajarr are still available" (Admit, 1978: 269; Admit, 1970: 114). Meanwhile, despite the fact that the development of Iranian nationalism and chauvinism are mainly indebted to Mirza Aqa Khan Kermani and his books "Mirror of Alexander", "Three Treaties" and Hundreds of Sermons", the contribution of Akhoundzadeh should not be neglected.

In his intellectual evolution, Akhoundzadeh developed from nationalism into chauvinism. In his letters to Maneckjiand and Jalaluddin Mirza Qajar as well as in his Writings, Akhoundzadeh was anxious to portray his identity in light of the anti-Arab and anti-Islam views. Radical nationalism or chauvinism in the ideas of Akhoundzadeh and Kirmani was accompanied with the denial of Arab ethnicity.

\section{General Approach of Intelligentsias to Chauvinism}

Amongst the most influential groups in the Constitutionalism, besides the clergy and the people, was a group, which for their commitment to the Western ideas and proposition of views contrary to those of society, was called intelligentsias. In analyzing the issue of chauvinism in the Constitutional Era, it is worth mentioning that the writing of the press and intellectuals were different. In the former, although the issue of nationalism of mythological narratives was under spotlight, it was never transformed into chauvinism. In this period, some of the newspapers have signs of national narratives in their names and front page including Kaveh and Jame Jam. Sourasrafyl is also among the newspapers propagating national narratives.

The second issue of this newspaper is seen as the first elaboration on "Kambiz, the Achaemenid king" (Sourasrafyl, 24 Rabi Al akhr $1325 \mathrm{AH}:$ 1). In other issues of this newspaper, there are columns on Mazdak and Anoushiravan (ibid.10 Shaban1325AH: 7) and the history of ancient Persia, Darius Achaemenid, Zal and Kaveh (ibid : 21 
Shawwal 1325AH: 3-2), but still there is no sign of anti-Arabism.

Other publications in this period focus on female mythological characters like "Manijeh", the daughter of Afrasiab (Shokoufeh, 5 Rabi al aval 1332AH: 3) and "Homa Bahman Dokht" (Habl al-Matin Weekly, 16 Shawwal 1324AH: 8-7). Further, in the social struggles and demands of women, references are made to the story of Zahak and the movement of the Blacksmith Kaveh (Zaban Zanan, 24 Ramazan 1338AH: 1). The important point is that in none of these press, the trace of anti-Arabism and chauvinism are observable.

In connection with the concept chauvinism in the attitudes of intelligentsias of in this period such as Mirza Malcolm Khan, Tolibov Tabrizi and Mostashar al-Doula, what is significant is the absence of chauvinism approach, especially antiArabism, though it is evidently projected in the works of Akhoundzadeh and Mirza Aqa Khan Kermani, a subject that will be discussed later.

\section{Biography of Akhoundzadeh}

Mirza Fathali, the son of Muhammad Taqi Mirza Fath Ai was born and bred in the year 1850 AH in Azerbaijan (Akhundzadeh, 1978: 250). His father, the mayor of Khameneh Village, married Lady Nanah, the nephew of Mullah Haji Ali Asghar, who gave birth to Fathali (ibid: 349). Mirza Fatali inherited his last name from his uncle in law, Haji Akound Ali Asghar, going by the name Akhoundzadeh (Admit, 1970: 10). Because of the conflicts between Nanah, the mother of Fathali, and the first wife of Ali Mirza Taqi, Fathali along with his mother returned to Haji Ali Asghar, who assumed the responsibility of raising Fathali(Akhundzadeh, 1978: 349).

The meeting with Mirza Shafi flared up his hatred against the clergy and made him revisit his "intention" (ibid: 351; Kia, 1995: 423). He then became interested in learning Russian, which was later continued by his work as Sunna Sharqia translator (ibid: 351). His mastery of Russian explains the influence of many intellectual Russian playwrights and poets on his thoughts (Mirsky, 1949: 227) which was then extended to the ideas of Voltaire through Pushkin and Gogol (Ganjbakhsh 2008: 131). In the realm of literature, besides a mastery of Russian texts, he was conversant with English literature and was regarded by many as the main" activist" in this field (Parsinejad, 2003: 42-4). His predilection toward literature was more "politically motivated" (Bashir, 1995: 20). In fact, he used literature as an efficient means to express his Western-influenced views and opinions.

His intellectual attitude was deeply rooted and non-negotiable (Ajoodani, 2008: 42) and he held opposing views against religion and non-religious beliefs (Kia, 1998: 475). Such an opposition is evident in his works especially the writings of Kamal al-Doule.

Despite his anti-religion writings, he adopted a different approach toward Zoroastrian, which was more a clear sign of his fanatic nationalism rather than his religious belief in Zoroastrian (Haeri, 2008: 29)

In the ventilation of anti-religious sentiments against people like Mostashar al-Doule who argued for the consistency of Islamic and Western concepts, have asserted that "since the Hijra onward, we have been persistently suffering, yearning for freedom of thoughts in our dreams".

Akhoundzadeh was the first intellectual of his time who "defended the rights and fought against the oppression of women" in the Caucasus and Iran. Emancipation of women, abolition of polygamy and complete equality of women and men in all social rights" as well as "attempts to grant greater freedom to women" constituted the major pillars of his thoughts (Kia, 1998: 475; Admit, 1970 143). He died in 1295AH in Tbilisi at the age of sixty-six.

\section{Chauvinism in the Works of Akhoundzadeh}

To explore the emergence of chauvinism in the thoughts and works of Akhoundzadeh, first his relationship with Jalaluddin Mirza Qajar, the son of Fathali Shah should be investigated.

In correspondences between Akhoundzadeh and Jalaluddin Mirza, which have been mentioned in the "The new alphabet and literature", there are seven letters written by Akhoundzadeh to the Qajar prince and four letter written by Jalaluddin Mirza to Akhoundzadeh. This relationship was initially built upon the familiarity of Jalaluddin Mirza with Akhoundzadeh upon which the Qajar prince sent "The book of Kings" to Akhoundzadeh through Ali Khan, the son of Rizwan, in Tbilisi (Akhundzadeh, 1978: 171).

Jalaluddin Mirza Qajar who had authored the "Book of the Kings" in celebration of nationalism (Jalaluddin Mirza Shah, 1976: 3) and his "great" fascination with "ancient" Iran is manifested in this book and his letters to Akhoundzadeh (Fashahi, 1975: 421), offered this book to Akhoundzadeh in their first encounter.

In his first letter to Jalaluddin Mirza, Akhoundzadeh suggest to divide the book into "five chapters to revive the memory of Persian Kings whose grandeur has not been immune to the invasions of Arabs (Akhoundzadeh, 1978:373). 
He also points that the conditions of our country "which used to be the heaven on earth, is now deplorable and has brought upon us unfathomable shame, humiliation, servitude and cruelty" (ibid: 172) and it should be changed.

The epitome of chauvinism in the works of Akhoundzadeh is his letters to Jalaluddin Mirza Qajar and Maneckji, the leader of Zoroastrian in Tehran. It consists of a total of twenty-two letters between Akhundzadeh and these two figures. The hatred of the Arabs and fascination with the ancient history of Iran is evident in their correspondences.

In a letter to Jalaluddin Mirza, he points out, "We knew that Arabs burned the only library of Egypt to ground and thus destroyed the science and technology of the ancient world, but we had recently found that "this wicked race [Arab] did the same to Persian books and letter "(Akhundzadeh, 1978: 220).

Maneckji also visited Mirza Fatali through Jalaluddin Mirza. In the year $1908 \mathrm{AH}$, he refers to the "Jamshidi celebration and Sun festival" in one of his letters, explaining that he learned about Akhoundzadeh through Prince Jalaluddin Mirza Rad "and "Moqarbalkhaqan Mirza Yusuf Khan". (ibid .: 80-387). In response, Akhoundzadeh expressed his "utmost pleasure" from knowing Maneckji, stating that he was a reminiscent of the Iranian ancestors (ibid: 249). Mirza Fatali points in his letters to the "covenant of culture" in the ancient Iran and praises "Minouneshan" (ibid: 250). Accordingly, it can be said that Maneckji and Jalaluddin Mirza fueled the sparkle of nationalism in Akhoundzadeh. These also were the only people with whom Mirza Fatali openly discussed "culture of ancient Iran and its glorious history.

The Writings of Kamal al-Douleh, another work of Akhoundzadeh, despite being a political and philosophical treatise with an anti-religion approach that portrays the social conditions of Muslims and "Islam", is not devoid of chauvinism (Ajoodani, 2002: 63). Writings of Kamal al-Douleh, as a "critical essays on politics and religion" (Admit, 1970: 114 ) is his most comprehensive work on anti-religion attitudes. In his chauvinistic approach, "the love of ancient Persia is in tandem with the "hatred of Arabs (ibid: 119). This book was never officially printed in Iran, but it became popular amongst the constitutional intellectuals and Agha Khan Kermani composed his "Three Treaties" in imitation of the style of this book.

Within chauvinism framework, although people like Muhammad Shah Qajar took advantage of Persepolis artifacts to "absorb the culture of the West" but others like Aqa Khan Kermani, who were committed to the writing style of Akhoundzadeh, used the carvings for their "anti-Islam and anti-Arab" intentions (Tavakoli Toroghi , 2003: 51). Such nationalism in the view of Akhoundzadeh and his followers in the course of self-representation has been manifested in the form of anti-Arabism where Arabs were the "scarecrow" responsible for all the calamities brought upon Iran (ibid: 54). Hence, in the "covenant of culture" he speaks of "the justice of Anoushiravan and Fereydoun" and after a eulogy of "grandeur", "power" and "prosperity" of Iran, addresses it as such "Oh Iran, barbarian and hungry Arabs have plagued you for one thousand two hundred and eighty years (Akhundzadeh, 1985:11). This revulsion and desperation sentiments are also expressed by Jalaluddin Mirza (Akhundzadeh, 1978: 175).

In the first treatise of the Writings, he regards Arabs as the root of the Iranian plights (ibid:15). He describes Arabs as a group "of savage vagrants who earn their living through plunder and pillaging" (ibid: 24). In the second treatise, he deviates from the chauvinism and levels criticism against religious beliefs such as eulogies and clergies like Muhammad Baqir Majlisi (ibid : 30-25). In the third treatise, he discusses "openness" in the sense of unveiling of women, referring to Dorat al-Taji, "the wife of Ali Zikr al-Salam Ismaili and Zarin Taj Gharat al-Eyn as the forerunners of this movement (ibid: $60)$.

In his line of thinking, patriotism is associated with a sense of chauvinism and "humiliation of other nations" (Ajoodani, 1985: 24). This attitude, however, is not only manifested in the ideas of Aqa Khan Kamali, but also traceable in people like Mirzadeh Eshghi in the play "Black Shroud" despite "the anti-Arab sentiments (ibid.). He first focused on the nationalism spirit which was followed by a dissident view of religion where he argued that rational opposition against religion was the "spiritual delight of the wise" and "anguishing in the pain of prayers and fasting" was "the self-pleasure of the fools" (Akhoundzadeh, 1972: 240). In his political ideas, nationalism verges on chauvinism and with passionate fascination with the ancient Iran and anti-Arabs sentiments, he points out the factors contributing to the decline of the Sassanid, positing that Arabs are the underlying cause of this decline (Fashahi, 1975: 345 ).

What could be regarded as a critique of his attitude against "despotism" and theory of chauvinism was that his criticisms of authoritarian regimes or despots, were only leveled against the system of Iran, irrespective of the autocratic Tsarist Russia under which he operated. His theory of chauvinism was exclusively concerned with Arabs, turning a blind eye to the actions of Tsarist Russia and the Russian war against Iran. In some of his treaties such as Writings of Kamal al-Doula, he enlists the prominent figures in ancient Iran regardless of the time and place, oblivious to the fact that in the political actions of ancient times, some of those people had waged war against one another. 


\section{Biography of Mirza Aqa Khan Kermani}

Abdul Hussein Khan Bardsiri known as Mirza Aqa Khan Kermani was born in1270 AH in Bardsiri, Kerman and died in the year 1313AH in Azerbaijan. He was initially attracted to Shaykhi, but soon he turned away from that sect, writing a treatise on the rejection of Mashallah Shaykhi exposition. After gaining access to the court of Zal al-Soltan in Isfahan and migrating to the Ottoman territory, he married Rafatollah (the daughter of Sobhe Azal, the leader of Bábism) and published the treatise of Eight Paradises with the aid of Shaikh Ahmad Ruhi, the husband of his sister in law, in the defense of Bábism (Admir, 1978: 18; Ajoodani, 2008: 497).

The hatred of Agha Mohammad Khan Qajar is illustrated in the ballads of Kermani people (Rezazadeh Malek, 1975: 103). The invasion of the founder of the Qajar dynasty to Kerman and the massacre of its people under the pretext of protecting Lotfali Khan Zand, was the root of this deeply- rooted revulsion. The collaboration of Kirmani with "Akhtar" newspaper and Mirza Malcolm Khan and the support of Seyed Jamaluddin Asadabadi are some of his protests against the Qajar. It is said that his inclination toward "Bábism" was largely rooted in the opposition against Qajar. He was assassinated on the order Mohammad Ali Mirza Qajar in the year $1313 \mathrm{AH}$.

\section{Anti-Arab Approach of Mirza Aqa Khan}

In the analysis of chauvinism in Kermani ideas, it should be noted that anti-Arab sentiments are absent in some of his works like Rizwan. This book is composed of an introduction and four chapters: chapter 1 is about the love story and the adventures of the youth; chapter 2 is about moral edification and the outcomes of research and education; chapter 3 is about the life and customs of the Kings; chapter 4 is about the subtleties of speech making, and the concluding chapter is a description of wisdom of traditions and moral lessons (Kirmani, 1948: 22). Unlike Mirror of Alexander and Ancient Manuscript, this book is not about the national epic but rather a guide to kings. Among his works, the general tone of "Three Treaties" is anti-Arabism.

In his world, national narratives and stories are the means through which he portrays a nasty picture of Arabs. Exploiting an analogy between the grandeur of ancient Iran before the invasion of Arabs, he vividly illustrates the gravity of the "disaster" brought upon the Iranian. It seems that his account of historical facts is not accurate and he has been trapped in the radical feelings. Anti-Arab attitude based on fictional elements are presented in Three Treaties. For example, at one point he states that "Arabs ... seized the crowns and palace of Keiqobad and squandered it" (Kirmani, 2000: 238). Elsewhere, he describes the mythical characters, lavishing each with an admirable trait in an attempt to portray an exaggeratedly horrible picture of Arabs by aggrandizing the greatness of the above figures;"[they] destroyed the works of Bouzarjomehr, who was the sun of the realm of wisdom, and the writings of Jamasb, who was the source of knowledge, wisdom and the divine rules of Mazdak and the wonder of the creation"(ibid: 267). However, it does not mean that Mirza Khan was skeptical of the greatness of ancient Iran and only exploited ancient culture and literature as a means to his end.

For example, in a part of his book, he swear to "the palace of Persepolis and the crown of Keiqobad" (ibid: 181) and elsewhere recalls the great old days with regrets, "Oh Iran, where is the prosperity and grandeur of yours at the era of Kiomars, Goshtasb, Anoushiravan and Khosrow Parviz "(ibid: 119). It seems he looked upon the glory of ancient Iran with respect, blaming the invasion of Arabs as the root of chaos and troubles in the contemporary Iran. The origin of this fury and hatred should be sought in his patriotic sentiments. In Hundreds of Sermons, there are also national stories and narratives, insightful views of ancient Iran and anti-Arab tendencies. His profound sentiments about that glorious past are evident in his descriptions of the mythological characters: the robust body of Khosrow, the charming prance of Shirin, the sturdy figure of Bahram, the strong chest and muscles of Rostam, the charisma of Faramarz, the glory, splendor and awe of Goodarz, the dignity and gentleness of Jamshid, the face of Manuchehr, the figure and countenance of Fereydoun, the head of the blacksmith Kaveh, the shape of Jamasp's nose, the eyes and eyebrows of Lohrabs and the neck and arm of Nowshiravan, which all illustrate the charming shape and appearance of Iranians (Kirmani, 2005: 17).

The importance of Hundreds of Sermons is due to some mythical-historical analyses, which rather than being a scientific and theoretical reasoning, are derived from the individual taste and creativity of the author.

The Hundreds of Sermons along with Three Treaties, as the most important works of Kermani, are replete with chauvinism. In this treatise, the Arabs are described with designations such as "dishonest desert wanderers, lizard eaters, the shameless camel riders and disdainful thieves (Kirmani, 2005: 60). For him, Arabs are the underlying cause of Iranian degeneration. In the first sermon of his treatise, he points out:

"Oh Iran, the history of thy greatness and glory was burnt down by Arabs and trampled under the oppression of the savages such that even not a page of 2000-year history of Iran is extant (ibid: 1). 
Kirmani, expanding on his nationalist views, portrays the glory of Iranian history. In his description of the beauty and power of the mythical kings of Iran, he makes reference to "splendor and strength of Goodarz.", "the head of blacksmith Kaveh" and "face and countenance of Manuchehr (ibid: 17), who were all destroyed by Arabic plague (ibid: 16).

The keen interest of Mirza Khan in the cultures of ancient Iran finally made him elaborate upon thoughts, desires and analyses in an independent book entitled the Mirror of Alexander. This book, which is devoted entirely to the ancient Iran, divides the pre-Islamic period into four eras: the age of superstition and mythology of Abadian, the age of darkness of Ajamian and Pishdadian, the age of twilight of Kayanids and Parthian and the age of illumination of Sassanid (Kirmani, 2010: 32). This classification, rooted in the mystical ideas, suggests that he perceived the mythical era as the age of darkness, acknowledging the historical evolution approach for the developments of pre-Islamic era. "The illumination" of the Sassanid era, in his opinion, rather than being due to its distinctive role in the pre-Islamic era, is due to the fact that it represents the final stage of historical development of the Iranian. A belief in the equality of the myths and superstitions is also another flaw of his interpretations that are rampant throughout the book. Anti-Arab tendencies are evident from the first pages where, for example, where he says, "If it was not for Shahnameh Ferdowsi, after the conquest of Arabs, the identity of Iranians had been dissolved into that of Arabs" (ibid: 36). Further, he used the myth of Zahak to represent Arabs as Zahak, claiming that "The heinous conquerors of Iran, as depicted in Shahnameh, are Arabs" (ibid: 71).

In summary, amongst the works of Kermani, some like "Three Treatises" are in imitation of Akhoundzadeh's "Writings of Kamal al-Doula" and some like Hundreds of Sermons pay special attention to the issue of chauvinism in form of anti-Arabism.

\section{Conclusion}

With the rise of the French Revolution and introduction of reforms in line with the civil society approach and popularity of notions such as nationalism and chauvinism, Iranian intelligentsias, during their trips to Europe and in their relations with France, not only became familiar with those ideas, but also assumed the responsibility of their adaptation in Iran.

The idea of nationalism was conceived and flourished amongst the intelligentsias with the rise of Fathali Shah to power and the measures of Muhammad Shah. Mirza Fathali Akhoundzadeh and Mirza Aqa Khan Kermani were among the intellectuals who in their writings, letters and plays sought to address the issues of "justice", criticism of social inequalities", protest against the religious beliefs and concepts like "Homeland" in form of nationalism attitudes. He learned about philosophers like Voltaire through Russian intellectuals and attempted to introduce some aspects of Iranian nationalism by taking measures such as "reforming of handwriting and alphabet".

In his visit with Maneckji, the leader of Zoroastrian in Tehran, and Jalaluddin Mirza Qajar, Akhundzadeh adopted the chauvinism attitude and put his anti-Arabism on display. In twenty two letters exchanged between him, Maneckji and Jalaluddin Mirza, the most radical chauvinism views are expressed.

Even in works such as Kamal al-Doula that mainly deal with his anti-religion views, Akhoundzadeh, discusses the issue of chauvinism, blaming Arabs and Islam as the underlying cause of misery and adversity of the Iranian. Upon his acquaintance with the ideas of Akhoundzadeh, Kermani wrote his "Three Treatises" in imitation of "Writings of Kamal alDoula" of Akhundzadeh, which mirrors the influence of Akhoundzadeh in the inculcation of chauvinism in Kermani.

Among the works of Akhoundzadeh, his letter to Maneckji and Jalaluddin Mirza and "Writings of Kamal al-Doula" and in the works of Kermani, "Treatises" and "Hundred Sermons" are infused with chauvinistic ideas in form of antiArabism. Accordingly, these two intellectuals of pre-revolutionary era regarded Arabs as the main cause of the historical decline of Iranians.

\section{References}

Ajoodani, Mashallah (2008). Iranian Constitution, $9^{\text {th }}$ edition, Tehran: Akhtaran.

(2002). Death or modernity, a review of the Constitutional poetry and literature, $1^{\text {st }}$ edition, Fasle Ketab: London.

(1985). Poetry, Constitutional, anti-authoritarian, anti-colonialism, Nashre Danesh, No. 30: 29-16.

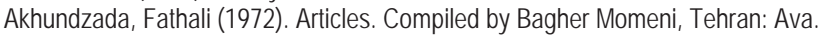

------- (1985). Writings, letters of Kamal al-Doula to Prince Jamal al-Dawla. Beja: Marde Emouz.

(1978) New alphabet and writings. Compiled by Hamid Mohammad Zadeh, Tabriz: Ahya.

Admit, Fereydoun, (1970). Thoughts of Mirza Fatali Akhoundzadeh, Tehran: Kharazmi

-- (1978). Thoughts of Mirza Aqa Khan Kermani, Tehran: Payam.

Assuri, Daryush. (1978). Political culture, Tehran: Morvarid.

Beshler, Jean, (1990). What is ideology? Translated by Ali Asadi (1 ${ }^{\text {stedition}) . ~ T e h r a n: ~ P u b l i s h i n g ~ C o m p a n y . ~}$ 
Bashiri, Mahmoud (1995). Analysis of the works and thoughts of Mirza Fathali Akhundzadeh Ashna, 5: 27.

Tavakoli Toroghi, Muhammad (2003). Local modernity and historical reconsiderations. Tehran: Tarikh Iran.

(1990). The influence of French Revolution in shaping the idea of constitutionalism in Iran. Iran Nameh, 31: 439-411. Jalaluddin Mirza, (1976). Book of the Kings. Tehran: Bina

Haeri, Abdollah (2008). Shi'ism and the Constitutionalism in Iran and the role of Iranian nationals in Iraq (8 th $^{\text {Edition}) . ~ T e h r a n ' s ~ A m i r ~}$ Kabir.

Reza Zadeh Malik, Rahim (1975). Susmar al-Doula. Tehran: Donya.

Kirmani, Mirza Aqa Khan, (1948 AH). Book of Rizwan, a manuscripts from the Library of Parliament, Retrieval No: 116723

Kirmani, Mirza Abdul Hussein Khan (2010). Mirror of Alexander. Compiled by Ali Asghar Haghdar, Tehran: Cheshmeh.

Kirmani, Mirza Aqa Khan (2000). Three treatises. Compiled by Behram Choobineh, Germany: Nima. -- (2005), Hundreds of sermons. Compiled by Muhammad Jafar Mahjoub, Los Angeles: Book Company.

Ganjbakhsh Zamani, Saeed (2008). A comparative study of the ideas of Voltaire and Akhundzadeh. Jiroft Comparative Literature (7): $147-125$.

Fashahi, Mohammad Reza (1975). From Gathas to the Constitution, a brief report of the intellectual and social developments in the feudal society of Iran, Tehran: Gothenburg

Parsinejad, Iraj (2003). A History of Literary Criticism in Iran (1866-1951) IBEX Publishers: United States

Gellner, Emest (1999). Nation and Nationalism, Oxford: Blackwell.

Mirsky, D.S. (1949) . History of Russian Literature: London.

Kia, Mehrdad (1998). "Women, Islam and Modernity in Akhundzadeh's plays and unpublished writings. Middle Eastern Studies, 34 (3): London.

\section{Newspapers}

Habl al-Matin (weekly), 16 Shawwal 1324 AH, Vol 14, Issue 17

Sourasrafyl, First Year, No. 2, 24 Rabi Miscellaneous 1325 AH.

Sourasrafyl, First Year, No. 14, 10 Shaban $1325 \mathrm{AH}$.

Sourasrafyl, First Year, No. 18, 21 Shawwal 1325 AH.

zabane zanan, Second Year, No. 29, 24 Ramazan 1338 AH.

Shokoufeh, Second Year,5 Number Rabi al sane $1332 \mathrm{AH}$. 